\title{
Status report: A Norwegian decriminalisation of use and possession of drugs?
}

\author{
JØRN JACOBSEN*, VICTORIA WESTRUM ${ }^{\star *}$
}

\section{Introduction}

As the article about Germany in this number of Bergen Journal of Criminal Law and Criminal Justice illustrates, many countries are in process of changing their approaches to drug legislation, in particular with a view to decriminalise minor involvement in drugs, i.e. possession of minor quanta of drugs or use of it. So is the case for Norway, where a drug reform has been proposed by the Government. However, the political fate of this reform is currently troublesome. As the development is of interest also beyond Norway, we will in this comment provide our readers with an update on the situation with the drug reform. Section 2 of this report will briefly outline the current state of law. Afterwards, in section 3, the Norwegian reform proposal will be explained. This section will contain the justification for the drug reform and the proposal itself. Finally, in section 4 we will describe the political disagreement that has emerged, leaving the reform in turmoil.

\section{The current Norwegian regulation of drugs}

The legal meaning of the term 'drug' in Norway is clarified in section 22 of the medicines act of 1992. ${ }^{1}$ The supplementary 'narcotics list' gives details about which substances that are considered as a 'drug' by Norwegian law. The involvement in such substances is regulated in two different codes, the penal code and the medicines act.

* Jørn Jacobsen, Professor at the Faculty of Law at the University of Bergen and editor in chief of BJCLCJ. Email: Jorn.Jacobsen@uib.no.

** Victoria Westrum, Research assistant at the Faculty of Law at the University of Bergen and editorial assistant for BJCLCJ. Email: Victoria.Westrum@student.uib.no.

$1 \quad$ Act 1992-12-04-132 on medicine (Lov om legemidler m.v.).

This is an Open-access article distributed under the terms of the Creative Commons Attribution 3.0 Unported License (http://creativecommons.org/licenses/ by/3.0/), permitting all use, distribution, and reproduction in any medium, provided the original work is properly cited. 
The provisions of the Penal Code on drug crimes are included in Chapter 23 of the Act, which aims to protect the public health and the external environment. ${ }^{2}$ Section 231 of the Penal Code prohibits produces, imports, exports, acquires, stores, sends or supplies a substance of drugs. ${ }^{3}$ The ordinary maximum penalty here is 2 years imprisonment. More serious drug offenses, i.e. cases where the maximum penalty are higher, are regulated by Section 232. In such cases is the maximum penalty 10 years. If the case concerns a very substantial amount of drugs, the penalty is minimum 3 years, maximum 15 years imprisonment. In cases of particularly aggravated circumstances, i.e. for cases of extensive and 'professional' involvement in trading of drugs, the offense can be punished with the law's most severe punishment of 21 years' imprisonment. Whether the case should be considered after section 231 or section 232 depends on the type of drug and quantity. Guidelines for this assessment can be found in the General Attorneys' circular which is based on the Supreme Courts' decisions. ${ }^{4}$

By the current state of Norwegian law, also use and possess of narcotic drugs entail criminal liability. ${ }^{5}$ This is however not covered by the criminal code, but the medicines act, where sect. 24 of this act concerns the less serious matters such as the use and possession for small quantities. According to section, it is considered illegal to use or possess narcotics, unless there is an alternative legal basis for such use. A relevant example is a prescription from a doctor. The penalty for breaches of this offence is a fine or imprisonment for maximum 6 months, see sect. 31 of the Medicines Act.

\section{Background for the reform work}

A reform of the contemporary criminal regulation of minor involvement in drugs is supported by several reasons. First of all, it should be pointed out that for the last 15 years Norway has been considered to have one of the deadliest drug policy regimes in Europe. Together with Sweden and Estonia, Norway has the most overdose deaths per citizen in Europe. ${ }^{6}$ This is concerning, especially taken into consideration that Norway is ranked as the best country to live in because of the high living standards

2 Jacobsen etal., Forbrytelseriutvalg - Straffelovens regler om voldsforbrytelser, seksualforbrytelser, formuesforbrytelser og narkotikaforbrytelser (Fagbokforlaget 2020) p. 267.

3 Act 2005-05-20-28 on punishment (Penal Code). See the english translation $<$ https://lovdata. no/dokument/NLE/lov/2005-05-20-28/KAPITTEL_2-8\#\%C2\%A7231> 24 June 2021.

4 Circular nr. 2/2014 from the General Attorney. See also Jacobsen et al. 2020 p. 290-291.

5 For a more detailed overview in English, see Jacobsen \& Taslaman, The Norwegian Criminal Regulation of Drugs: An Overview and Some Principled Challenges. 6(1) Bergen Journal of Criminal Law \& Criminal Justice (2018) pp. 20-52.

6 Marthinussen, Decriminlisation of Drug Use - The Outlook for Reform in Norway, Vol. 6 Issue 1 Bergen Journal of Criminal Law and Criminal Justice (2018) pp. 53-67, at 57. 
and good welfare and health system. ${ }^{7}$ The decriminalisation of drug use can also be supported by the harm principle. In question of whether an action or behaviour should be criminalised, the harm principle is in Norwegian criminal law considered as a main principle. This means that behaviour should only be made punishable if it leads to harm or danger of harm to interests that should be protected by society. ${ }^{8}$ It is difficult to argue that drug use creates danger for anyone but themselves. ${ }^{9}$ It should also be emphasised that the proposal of abolishing criminal liability for the use and possession of small quantities of drugs for personal use is in accordance with recommendations from UN bodies such as the UN Office for Drugs and Crime (UNODC), the UN Monitoring Body for the Implementation of the Drug Conventions (INCB), the World Health Organisation (WHO), and the UN High Commissioner for Human Rights (OHCHR). ${ }^{10}$

\section{The drug reform commission's proposal}

There has for some time been a tendency towards a historical shift regarding the Norwegian policy of criminalisation of use and possession, from a criminal law centred approach to a health centred approach. ${ }^{11}$ Such a shift would entail a transfer of responsibility, from the justice sector to the health sector. ${ }^{12}$ In line with this, a commission installed by the Government proposed to abolish criminal liability for the use of drugs in cases where the use and possession regards a small amount of drugs for own use. The commission consisted of jurists and others with experience from the municipal health and care services, the specialist health services, police and prosecutors, as well as representatives for drug users. ${ }^{13}$

The commission proposed a shift of track, by replacing criminal reactions against people who use or possess drugs for own use, with health oriented help in terms follow-up and treatment. This proposal did not imply legalisation of a defined amount of drugs for own use, but (only) decriminalisation of minor involvement in drugs. In-

7 Norway was ranked as number one on top in the UN's Human Development Index Ranking 2020. https://report.hdr.undp.org 9 May 2021.

8 Innst. O. nr. 72 (2004-2005) pp. 16-17. See also Gröning, Husabø and Jacobsen, Frihet, forbrytelse og straff, 2nd ed. (Fagbokforlaget, 2019) pp. 44-45.

$9 \quad$ NOU 2002:4 pp. 80-81 and 330-331. See also Jacobsen \& Taslaman 2018.

10 Cf. Prop. 92 L (2020-2021) Endringer i helse- og omsorgstjenesteloven og straffeloven m.m. (rusreform - opphevelse av straffansvar m.m. [Proposed legislative resolution regarding amendments to the Health and Care Services Act and the Penal Code, etc. (drug reform abolition of criminal liability, etc.)] p. 8.

11 Stoltenbergutvalget, Rapport om narkotika [Report about drugs] (2010) <https://www. regjeringen.no/globalassets/upload/hod/rappomnarkotika_nettversjon.pdf> 1 June 2021 .

12 Cf. Prop. 92 L (2020-2021) p. 7.

13 Cf. NOU 2019: 26 Rusreform - fra straff til hjelp [Drug reform - from punishment to help] p. 18. 
stead of a criminal sanction there would be imposed a duty - by the police - in terms of a taking part in a meeting with a municipal advisory from the health care service. The purpose of this meeting would be to give the person in question information about the risks and possible consequences of drug use and offer the necessary treatment and follow-up if the person consents. A duty like this was meant to underline the fact that drug use is still prohibited because it entails sanctions for the citizen. ${ }^{14}$

The committee proposed that impunity for drug use should depend on two conditions. First of all, the amount should not exceed the various threshold values for different type of narcotics drug. The other condition was that the drugs were for own use, not sales and distribution. The proposed reform thereby concerned primarily the criminalisation of use and possession of minor quanta for the purpose of own use, and purchase of this, not other kinds of involvement in drugs such as import, production or trading of drugs. The regulation in the penal code would thereby to a large degree be unaffected by the proposed reform.

The table below shows the committee's proposal for threshold values, both the majority and minority. To determine the various values, relevant material was obtained from The National Criminal Investigation Service (Kripos), The National Institute of Public Health (NIPH/FHI) and other relevant contributors who have valuable experience in the field of drug users. ${ }^{15}$ 


\begin{tabular}{lcl}
\hline Narcotic drug & The majority & The minority \\
Heroin & 5 gram & 1 gram \\
Cocaine & 5 gram & 1 gram \\
Amphetamine & 5 gram & 1 gram \\
GHB, GBL \& 1,4-butandiol & 1 deciliter & 0,5 deciliter \\
LSD & 3 patches & 1 patch \\
MDMA & 1 gram & 1 gram \\
Cannabis & 15 gram & 5 gram \\
Mushooms \\
containing psilocin / psilocybin
\end{tabular}

Table: The committee's proposal for threshold values regarding impunity drug use. ${ }^{16}$

The order to appear at the municipal advisory unit for drug cases would only be given when it was highly probable that the person used or attempted to use drugs, likewise if they had or had attempted to acquire drugs for their own use or possessed or have contained drugs for their own use. ${ }^{17}$ The drug reform meant that the responsibility regarding the state's sanctioning for use and possession of drugs for own use was transferred from the justice sector to the health service in each municipal.

The suggested name for the unit was - 'rådgivende enhet for narkotikasaker', i.e.: 'the advisory unit for drug cases. The committee stated that the unit had to be able to provide adequate and adapted advice and guidance on the risks and consequences of drug use, as well as information about help services available to all user groups. ${ }^{18}$ At the meeting the person would be given general information about the drug in question, the consequences of drug use, and recommendation to not continue the drug

\footnotetext{
16 Ibid.

$17 \quad$ Ibid. p. 55.

$18 \quad$ Ibid. p. 58.
} 
use. ${ }^{19}$ The duty to attend the meeting should as mentioned, not imply an obligation to accept an offer for mapping of the drug use, adapted counseling or referral for further follow-up for drug abuse problems. ${ }^{20}$

\section{The proposal from the Government}

The Government accepted the main ideas in the committee proposal but did still some significant changes in it, as it launched its law proposal in Prop. 92 L (20202021) Endringer i helse- og omsorgsloven og straffeloven m.m. (rusreform - opphevelse av straffansvar m.m.). A fee for non-compliance, i.e. failing to attend the meeting one is ordered to take part in, was proposed. This was justified by a claim that it may have an individual and general preventive effect to avoid a breach of the duty to attend. In particular, it was claimed, this may apply to young users and for experimental or recreational users. It is also stated that sanctioning would appear as an educational tool to emphasise that drug use is still prohibited. ${ }^{21}$ Furthermore, the Government did not accept the same threshold values that the committee but opted for one lower limit and one higher - where only cases below the lower threshold would be decriminalised. Cases in between the lower and higher threshold values should, as the main rule, not be prosecuted by the police. The government's proposal also contained other important deviations from the report, such as amendments to the police law.

\section{Reactions to the Government's reform proposal}

The drug reform raises a broad public debate, including some disagreements between the political parties. They agreed on that one should not punish addicts who have a heavy drug problem, but rather offer them help. Apart from this, there was a number of diverging opinions on the reform. A central viewpoint for those who were clearly skeptical to it, was the fear for the consequences of not punishing young people for involvement in small doses, typically for party use. It was discussed, among other things, whether young people should be invited to more than one meeting in the municipality. Some parties also demanded improved help services for addicts. ${ }^{22}$ Another central issue in the debate was the role of the police. Some were concerned that the reform would deprive the police of important competences, while others pointed to excessive and unlawful use of force against and control of drug users under the current regime. In the parliament, there

Ibid. p. 45 .

Ibid.

Ibid.p. 48.

Ruud, Rusreformen er helgens hotteste sak. Her får du reformen kort oppsummert ['The drug reform is the hottest issue of the weekend. The reform briefly summarized'], Aftenposten (2021). $<$ https://www.aftenposten.no/norge/politikk/i/AlnLBr/rusreformen-er-helgens-hotteste-sakher-faar-du-reformen-kort-oppsumme> 10 May 2021. 
was no clear majority for the government's reform proposal. ${ }^{23}$ The Labour party ('Arbeiderpartiet'), which proved decisive for the outcome of the reform, stated that they wanted a solution that made it possible to react differently to young users and heavy addicts. A solution like this, which will involve a decriminalisation only for heavy addicts was however criticised from constitutional points of view. ${ }^{24}$

The government parties did not endorse this alternative to its own reform proposal. Thereby, a majority for the reform proposal could not be reached, leading to the rejection of the reform. Only some minor amendments, responding to some of the most pressing problems relating to the contemporary regulation, was agreed on. ${ }^{25}$

23 See Innst. 612 L (2020-2021) Innstilling fra helse- og omsorgskomiteen om Endringer i helseog omsorgstjenesteloven og straffeloven m.m. (rusreform - opphevelse av straffansvar m.m.) og om Representantforslag fra stortingsrepresentantene Jan Bøhler, Per Olaf Lundteigen, Kjersti Toppe og Trygve Slagsvold Vedum om at rusavhengige ikke skal straffeforfølges.

24 The Norwegian Constitution section 98. See also Jacobsen \& Vogt, Avkriminalisering bare for tungt rusavhengige vil stride mot Grunnloven ['Decriminalisation only for heavily drug addicts will be in conflict with to the Constitution'], Rett24 (2021). <https://rett24.no/articles/ avkriminalisering-bare-for-tungt-rusavhengige-vil-stride-mot-grunnloven>10 May 2021.

25 For an overview of the reform, related documents, and its outcome, see Sak - stortinget $<$ https://www.stortinget.no/no/Saker-og-publikasjoner/Saker/Sak/?p=8355> 18 June 2021. 